\title{
The Effect of Compensation and Benefits Towards Employee Performance
}

\author{
Adibah Abdul Kadir ${ }^{1}$, Adnan Ali Hassan Humaid AlHosani ${ }^{2}$, Fadillah Ismail ${ }^{3}$, Norseha \\ Sehan $^{4}$ \\ \{adibah_kadir@yahoo.com ${ }^{1}$, adnan.fpd@ sewa.gov.ae ${ }^{2}$, fadillah@uthm.edu.my ${ }^{3}$ \} \\ ${ }^{1,2,3,4}$ Faculty of Technology Management and Business, Universiti Tun Hussein Onn Malaysia, Malaysia
}

\begin{abstract}
Nowadays, taking care the welfare of the employee is very important in order to ensure them to hard work in achieve the organizational goal. The aim of the study is to establish the effect of compensation and benefits towards employee performance. The objective of this research is firstly, to evaluate the level of employee performance. Secondly, this research aims to examine the relationship between compensation and benefits towards employee performance. Lastly, determine the effect of the compensation and benefits towards employee performance. This research carried out at XYZ College. This study used the survey research method where 100 questionnaire were distributes among lectures of XYZ College with population of 100 lectures which make the sample is 80 respondents. The data collected were analysed and interpreted using the Statistical Package for Social Sciences (SPSS). Based on the result, it is found that the performance level of lecturers is at medium and high level. In addition, there is a positive correlation between compensation and employee performance. Moreover, the compensation and benefits also give a positive effect on employee performance.
\end{abstract}

Keywords: Compensation, benefits, employee performance

\section{Introduction}

Malaysian should aim to be in the top country in term of economy, citizen well-being and innovation by taking care of the employee welfare to increase their performance. The welfare for employee cannot be ignored. Some of the company are taking care of the employee wellbeing by providing compensation and benefits in term of remuneration, allowance, promotion, and also incentive. The compensation and benefits is given based on employee performance. Employees' compensation is all form of pay and rewards going to employee and arising from their employment [1]. While, the benefits is indirect financial and nonfinancial payments employees receive for continuing their employment with the company. Currently, compensation and benefit plays a significant role for the organization that aim to accomplish their objectives and goals. The poor compensation and benefits will lead to low performance and that will lead to low satisfaction level that will increase absenteeism in employee and the outcome will decrease [2].

Usually, the compensation and benefits will be given based on the employee performance. Performance-enhancing compensation practices are designed to increase employee productivity through greater accountability, while highlighting performance differentials across employees [3]. Employees are one of the organization valuable resources because an organization cannot be operating if there is no human being to manage and handle the whole operation process. However, the employee that was hired must have a good quality in order to make them as a valuable resource or the company assets. More and more 
organization especially those in the service sector have attuned to the idea that there is not much point in employing people at all if you are not going to take steps to make them want to give their best for you [4].

\subsection{Research Background}

The organization's reward system can play a critical role in influencing employee performance [3]. The higher education institution play a significant role in developing skills, and increased economy, therefore, high quality staff is required [5]. There are different between compensation and benefits. Compensation is more to financial payment while benefit is non-financial form of value. The benefit is the addition of the payment of employee or compensation that provided. Compensation and benefits is a given because of employee contribution to organization. In order to make sure that they give the best service to the university, the academic organization must satisfy the need of the academic staff. The basic compensation and benefit that the lecturers of XVY College received are the remuneration, allowance, promotion, and also incentive. According to a study on work life balance of a career women shows that, motivations to work, demographic factors, marital status, number of hours per week, working overtime, management's commitment to improve Work Life Balance, time for personal wellbeing do not affect work life balance of female employees; instead, satisfactory compensation is a distinguishing factor influencing their work life balance [6]. Thus, this study conducted to analyse the effect of the compensation and benefits towards lecturers of XYZ College's performance.

\subsection{Problem Statement}

For this study, compensation and benefit for the employee has it problem during the process. This is because, sometimes there are unfair compensation to the employee because of the bias of the manager. The allowances are not provided on fair criteria [2]. Besides, many employees do not understand about the compensation and benefits. Most of the employee thought that the compensation and benefits is only viewed as cash. Compensation and benefits is usually narrowed to cash and as result, employers only have a tunneled vision when it comes to the issues of compensation for their employees [7].

Prior research has sought to identify a "pay for performance" relationship in executive compensation, but discovered no clear link between presidential salaries and performance measures [8]. However, the poor compensation and benefits will lead to low performance, thus lead to low satisfaction level and increase absenteeism in employee and the outcome will decrease [2]. The organization that manage compensation and benefits of the employee poorly will decrease the motivation of the employee to work harder [9]. Ccompensation is very important for the performance of employees. Compensation pertains to all the extrinsic rewards employees receive in exchange for their work [10]. Whenever there is low level of employee satisfaction in any organization, the employees of that organization will intentionally leave that organization. The high level of employee turnover has negative impact to organization economy and social processes. The organization profitability and productivity will be reduced because of the employee turnover.

\subsection{Research Question}

1. What is the level of employee performance? 
2. What is the relationship of the compensation and benefits towards employee performance?

3. How the compensation and benefits affect the employee performance?

\subsection{Objective}

The overall objective of this research is to analyze the compensation and benefits on the employee performance while, the specific objectives of this research are:

1. To evaluate the level of employee performance.

2. To examine the relationship between compensation and benefits towards employee performance.

3. To determine the effect of compensation and benefits towards employee performance.

\subsection{Research Scope}

The population pools of this study are the lectures of XYZ College. The sample of this study is 80 respondents. This research was conducted in Sri Gading, Batu Pahat, Johor. The probability sampling is used in this research since the number of the population selected is known. This research was conducted by using the quantitative method. The questionnaire were distributed among the sample of population.

\subsection{Significant of research}

This study was conducted to obtain more information about the effect of compensation and benefits towards employee performance among XYZ College's lecturers. This study is very important to the employee, academic institution and for the future research. The compensation and benefits is very important in increasing the employee motivation to perform well. This is because; it can improve the life of the employee and secure their life in the future. The employee will raise their performance so that they will get the bonus or promotion as the compensation and benefit.

Besides, the good compensation and benefit plan will increase the retention engagement of the employee. The employee turnover will be decrease and this will save the organization cost in recruiting new employee. To recruit the new employee, the organization will have to spend money in sending the new employee for training. In addition, this study also can be one of the reference sources to other researches who are interested to study the subject in deeper.

\section{Literature review}

\subsection{Definition of Compensation}

For an organization to supervise compensation efficiently, the employer need to have a positive influence on the performance of its employee, and understand the various aspect of compensation as motivators that motivate employees and direct their behavior towards achieving organizational objectives [7].

Generous reward retain employee and ultimately lead to job satisfaction, commitment and loyalty. Compensation is the reward that workers receive for their service or contribution to the organisation [11]. Meanwhile, the other author stated that compensation is a systematic approach to provide monetary value and other benefits to employees in exchange for their work and service [12]. 


\subsection{Definition of Benefits}

Employee benefit is defined as any form of reward provided by the organisation other than wages or salaries that is paid for in whole or in part by the employer [13]. The benefit also referred as indirect compensation because it is given to employees in the form of a plan (such as health Insurance, organization shares and retirement benefits) rather than cash [14]. Employee benefit can be referred to the benefits that are provided to the employees in addition to their salary [15]. Benefit includes packages an employer practices to supplement the cash compensation that employees receive. In other hand, benefit comprises of health, income protection, savings and retirement program that provide security for employees and families [5].

Employee performance can be seen as an activity in which the individual can achieved the task assigned to it successfully, subject to the usual constraint of the reasonable use of available resources [16]. Employee performance will exchange the fate of the organization with the hard work and good performance that will increase the productivity, and indirectly, increase the profit. Therefore, as the retribution the employee should be reward.

\subsection{Different between Compensation and Benefits}

Compensation is one of the elements of reward that is provided by company [17]. Benefit is part of the compensation; however it will distinguish by the types of rewards that will be given. Usually, the compensation will be given as the monetary rewards while the benefits will be given as non-monetary reward. These two rewards also known as the direct compensation and indirect compensation. Employee compensation can be seen as all form of financial and significant benefit received by employees as part of the employment relationship [18]. Direct compensation can be like salary or wages while indirect compensation can be as welfare support facility [19].

For this research, the compensation included are the remuneration and allowance while the benefits included are the promotion and incentive. This study was conducted at XYZ College which is education institution in government sector. There is a different between the government and private sector. The wages and salaries of local employees and the state are lower than private sector workers with earnings comparable determinant such as education [20]. However, the benefits such as pensions consist of sharing worker compensation in the public sector are better.

\subsection{Types of Compensation}

\subsubsection{Remuneration}

The remunerations are the payment or rewards given to the individual for work that have been done [21]. Remuneration is including the salary and wages. Wages and salary are defined as the monthly payment that employers pay their employees for service rendered based on contractual agreement [22]. When the administration paid remuneration in the reasonable time and fixing the salaries, the performance of the employees habitually growth [23]. Wages are the major and extremely significant motivational aspects that influence the employees' performance in the organization [24]. The remuneration is a challenge for the Human Resource area because it would pursue trends [25]. This is because the salary and wages is not the only ways to retained talented employees in organization. Most of the employees are looking into job that is securing all of their welfare. 


\subsubsection{Allowance}

Employee allowances including pension, salary sick, insurance coverage, car companies and several other benefit [26]. It is the money that provided to an employee for a specific purpose. Allowance is a financial benefits other than the salaries offered to employees for specific purposes such as employee movements, financial support and employee engagement allowances [11]. The high allowance can engage their employee to still remain at the organization and give their devotion and show their loyalty. The long term employee expands more knowledge and expertise in doing their job based on the long experience. However in each country and profession the use of allowance is different. There are country and profession that have allowance for certain job types, project, working hour or regime and location [27].

\subsection{Types of Benefits}

\subsubsection{Promotion}

The promotion is the redemption of worker to higher class [28]. Promotion is the recognition of employee effort in the organization. Recognition is required in a social and organizational environment as a motivational tool to produce good results [29]. Promotion is likely important in increasing employee performance because the upwards movement of employee rank in the organization will increase the motivation of employee and their sense of responsibility. The employees in the high rank feel more pressure in increasing the organization performance. Besides, enrichment and promotion task consistently in an institution is the ultimate desire of every employee [30].

\subsubsection{Incentive}

Incentives are reward offered in addition to the basic wage or salary directly related to the performance [31]. Besides, incentives known as a performance-based compensation system that links employee compensation to the achievement of workers who works directly in the workplace [32]. The non-monetary incentive include the indirect payment of money in the form of tangible rewards such as gift cards, trophies, vacation trip, meal treats and so on [33]. The positive effect of incentives are used as a lead to show employees what organization wanted to accomplish and what they assess and prioritize as significant to their work [34]. Besides, incentives can be used as an effective tool to attract employee who are desirable, authoritative into the organization, because employee who appreciate this form of magnetism will be interested to work there rather than employee that only looking for steady benefits.

\subsection{Definition of Employee performance}

Employee performance is the successful completion of task, responsibilities or assignment by selected employee or group of employee based on a set of performance objective and indicator of efficiency and effective utilization of available resources [35]. Besides, employee performance can be seen as an activity in which the individual can achieved the task assigned to them successfully, subject to the usual constraint of the reasonable use of available resources [16]. Employee performance is the achievement of set of standards in terms of accuracy and completeness over a specified period of time [36]. Employee performance will exchange the fate of the organization. With the hard work and good performance in increase the productivity, indirectly the employee is increasing the profit 


\subsection{Measurement of Employee Performance by their adaptive performance, contextual performance and task performance.}

The triachy model of employee performance has three dimensions which is adaptive performance, task performance and contextual performance [37]. As a component of overall employee performance, adaptive performance refers to the ability of the individual to change his behaviour to a new environment [38]. It is convenient that adjustment to changes in the environment take place at all levels in the organization, beginning with their employees [39].

Meanwhile, the task performance requires more cognitive capabilities and is especially facilitated through task knowledge (knowledge or technical principle require to ensure work performance and ability to handle multiple task, job skills (applying technical knowledge to achieving task successfully without much supervision) and task habit (build-in ability to respond to assigned task that either simplify or block [40].

Lastly, the contextual performance refer to activities that are not specific task or goals but that make individuals, teams and organization more effective and successful [41]. In addition, contextual performance includes collaborating and assisting other, voluntarily undertaking role activities, enduring with full enthusiasm and determination to successfully complete the task, defend organizational goals and comply with organizational policies even though this is inadequate. There is some evidence that contextual performance affects overall performance evaluation [42][43].

\subsection{Research Framework}

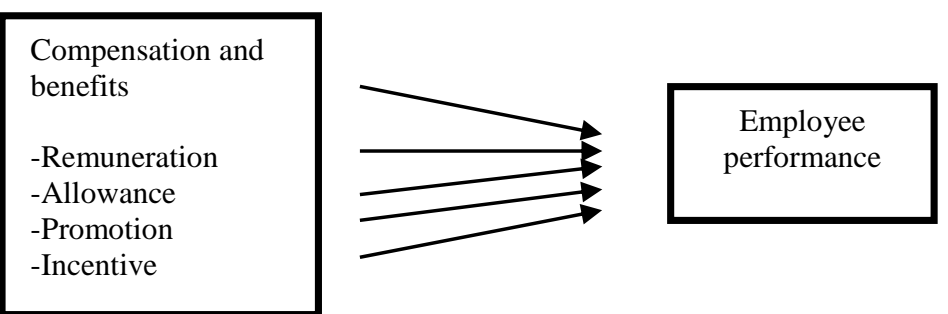

Figure 1: Research Framework

Based on Figure 1, remuneration, allowance, promotion and incentive are the elements in the compensation and benefits that will affect the employee performance such as adaptive performance, task performance and contextual performance. Thus, five hypotheses were formulated from the proposed model.

$\mathrm{H}_{1 \mathrm{a}}$ : There are significant relationship between compensation and benefits with employee performance.

$\mathrm{H}_{1 \mathrm{~b}}$ : There a significant relationship between remuneration and employee performance.

$\mathrm{H}_{1 \mathrm{c}}$ : There a significant relationship between allowance and employee performance.

$\mathrm{H}_{1 \mathrm{~d}}$ : There a significant relationship between incentive and employee performance.

$\mathrm{H}_{1 \mathrm{e}}$ : There a significant relationship between promotion and employee performance.

\section{Methodology}




\subsection{Research Design}

The research design is an empirical study. The research were conducted based on descriptive and correlational study. This research were conducted using the survey design which is a non-experimental setting.

\subsection{Population and Sampling}

For this study, the target population is the lecture at XYZ College which has a total number of 100 lecturers. The total sample is 80 lecturers that were selected randomly. A good sample size depends on three key factors namely, the level of confidence desired, the margin of error and the variability of the population [44].

\subsection{Instrument}

In this study, the researcher use quantitative research method to collect the data. Quantitative research method focuses on data collection from large number of consumers to obtain general cognition, objective method or research question phenomenon. This study used primary data and the main data collection technique used was structured questionnaire. The questionnaire used by the researcher as an instrument for the collection of data was divided by 3 sections. The questionnaire contains 32 questions. Section A is about the demographic of the respondent. Section B is about the benchmark of employee performance this questionnaire is adopted from Pradhan \& Jena [37]. While, section C measuring the compensation and benefits where the questionnaire is adapted from Feraro-Banta and Shaikh [2]. Section B and C was evaluated by using six-point Likert scale (1- Strongly disagree, 2- Disagree, 3- Somewhat disagree, 4- Somewhat agree, 5- Agree, 6- Strongly agree). Statistical Package for the Social Science (SPSS) was used to calculate the data obtained. This study utilized the quantitative methodology and follows a survey method design. The 100 questionnaires were distributed among the population and 86 were returned.

\subsection{Pilot test}

Pilot study is the foundation of good research design [45]. A pilot test will be conducted before collecting the actual data in order to assess the reliability of the research instrument. The purpose of using pilot test is to test the validity and reliability of the research instrument. A pilot test is done before an actual study is conducted. The Cronbach alpha value $(\alpha)$ is a reliability coefficient that has positive relationship with each other. The closer Cronbach alpha value $(\alpha)$ is to 1 , the greater the internal consistency of the item in the scale. The rule of thumb [46] as shown in table 3.4.

Table 1: Rule Of Thumb for Cronbach Alpha Value

\begin{tabular}{cc}
\hline Alpha Value, $(\mathrm{A})$ & Level \\
\hline$>0.9$ & Excellent \\
$>0.8$ & Good \\
$>0.7$ & Acceptable \\
$>0.6$ & Questionable \\
$>0.5$ & Poor \\
$<0.5$ & Unacceptable \\
\hline
\end{tabular}

(Source: George and Mallery, 2003) 
To complete the pilot test, a total 30 respondent were pick randomly to answer the prepared questionnaire. From the feedback received, the finding shown in the Table 3.2 which the alpha value is more than 0.941 for overall variable. The value shows that the alpha value obtained are excellent for this research.

Table 2. Reliability Statistics for Measurement Scales

\begin{tabular}{lccc}
\hline \multicolumn{1}{c}{ Variables } & $\begin{array}{c}\text { Cronbach's } \\
\text { Alpha (N=30) }\end{array}$ & $\begin{array}{c}\text { Cronbach's Alpha } \\
\text { Based On Standardized } \\
\text { Item }\end{array}$ & $\begin{array}{c}\text { N of } \\
\text { Item }\end{array}$ \\
\hline Compensation and benefits & 0.963 & 0.965 & 20 \\
Employee performance & 0.812 & 0.820 & 16 \\
Overall & 0.941 & 0.934 & 36 \\
\hline
\end{tabular}

\section{Findings and Data Analysis}

\subsection{Analysis of Demographic}

Table 3. Demographic Information

\begin{tabular}{|c|c|c|}
\hline $\begin{array}{l}\text { Demographic information } \\
\qquad(\mathrm{N}=86)\end{array}$ & Frequency & Percentage \\
\hline \multicolumn{3}{|l|}{ Gender } \\
\hline Male & 51 & 59.3 \\
\hline Female & 35 & 40.7 \\
\hline \multicolumn{3}{|l|}{ Age } \\
\hline Below 34 years old & 30 & 34.9 \\
\hline $35-44$ years old & 29 & 33.7 \\
\hline $45-54$ years old & 22 & 25.6 \\
\hline 55 years old and above & 5 & 5.8 \\
\hline \multicolumn{3}{|l|}{ Working hour } \\
\hline $6-8$ hour & 60 & 69.8 \\
\hline $9-11$ hour & 24 & 27.9 \\
\hline 12 hours and above & 2 & 2.3 \\
\hline \multicolumn{3}{|l|}{ Wages } \\
\hline Below 3,500 & 17 & 19.8 \\
\hline RM3,600- RM6,500 & 40 & 46.5 \\
\hline RM6,600-RM9,500 & 16 & 18.6 \\
\hline RM9,600 and above & 13 & 15.1 \\
\hline \multicolumn{3}{|l|}{ Years of working } \\
\hline Below 8 years & 24 & 27.9 \\
\hline $9-16$ years & 35 & 40.7 \\
\hline $16-24$ years & 16 & 18.6 \\
\hline 25 years and above & 11 & 12.8 \\
\hline \multicolumn{3}{|l|}{ Qualification } \\
\hline Degree & 28 & 32.6 \\
\hline Master & 58 & 67.4 \\
\hline
\end{tabular}


Based on result obtained, the percentage of male respondent is higher with 51 respondents $(59.3 \%)$ compared to the female respondent which is 35 respondents $(40.7 \%)$. Frequencies of the respondent's age were divided into four categories which is from below 34 years old to above 55 years old. Most of respondent age which is $34.9 \%$ is below 34 years old, while there are only $5.8 \%$ of the respondent ages 55 years and above. Table 4.1 also shows that most of the respondents are working between 6-8 hours which contributes to $69.8 \%$ respondent. The least of the respondent is working for 12 hour and above which contributes only $2.3 \%$ respondent. There are $27.9 \%$ respondents have between 9 to11 working hour. Majority of the respondent which is $46.5 \%$ received the wages between RM3600-RM6500. Meanwhile, the least respondent receives wages in between RM9600 and above which is $15.1 \%$. Most of the respondents which is $40.7 \%$ of them works at the organization for between 9 - 16 years, while there are only $12.8 \%$ of them have work for 25 years and above. For the academic qualification, most of the respondents are Master Degree holder which contributes to $67.45 \%$ while only $32.6 \%$ of the respondents are graduated with Bachelor Degree.

\subsection{Descriptive analysis}

In descriptive analysis, this section involved analysis of mean level and standard deviation. Table 4.2 below shows the extent level for mean.

Table 4. Extent Level of Mean

\begin{tabular}{cc}
\hline Mean Score Range & Level \\
\hline $1.00-2.24$ & Low \\
$2.25-3.49$ & Average \\
$3.50-4.74$ & High \\
$4.75-6.00$ & Very High \\
\hline
\end{tabular}

(Source: Tasmin \& Woods, 2008)

Table 5. Level of Employee Performance

\begin{tabular}{ccc}
\hline Level of employee performance & Frequency & Percent \\
\hline Average & 40 & 46.5 \\
High & 53.5 & 53.5 \\
Total & 86 & 100.0 \\
\hline
\end{tabular}

Table 4.3 shows the level of employee performance at XYZ College. $46.5 \%$ of the employees have an average level of performance, while $53.5 \%$ of them are at a high level. This shows that most of the employees at KKTM have a high level of performance while there are no employees that have a low level and a very high level of performance at workplace.

\subsection{Normality}

Normality Analysis is used to determine whether the study population is normally distributed or not. The $\mathrm{P}$ value range more than $0.05(5 \%)$ shows that the data is normally distributed and Pearson correlation test will be used. Conversely, abnormal data attribute to $\mathrm{P}$ value less than 0.05; Spearman correlation test will be used. There are two test commonly used in normality analysis which are Kolmogorov-Smirnov that used for large sample sizes of more than 50 respondents, while another test is Shapiro-Wilk Test which is more capable to be applied for the smaller sample size of less than 50 respondents. 
Table 6. Analysis for Normality Test

\begin{tabular}{lccc}
\hline & \multicolumn{3}{c}{ Kolmogorov-Smirnov } \\
\cline { 2 - 4 } & Statistic & Df & Sig. \\
\hline Remuneration & .214 & 86 & .000 \\
Allowance & .181 & 86 & .000 \\
Promotion & .180 & 86 & .000 \\
Incentives & .181 & 86 & .000 \\
Employee performance & .082 & 86 & $.200^{*}$ \\
\hline
\end{tabular}

Table 4.4 shows that the $\mathrm{P}$ value of employee performance is 0.200 . Therefore, Kolmogorov-Smirnov was used in this research where there are 86 respondents in this research. Since the result of the normality analysis in this research is normally distributed, Pearson correlation test were used.

\subsection{Bivariate Correlation Analysis}

The correlation coefficient is measures that determine the degree to which two variables' movement are associated. Since the normality test results shows that the data are normally distributed, thus, Pearson Correlation Analysis is used to examine the relationship between compensation and benefits with employee performance.

If the significant value at $\mathrm{p}$ is not more than 0.05 , it indicates that two variables are statistically significant, whereas, the significance value at $\mathrm{p}$ more than 0.05 , it shows that the two variables are not statistically significant. Table 4.5 shows the extent level of correlation.

Table 7. The Extent Level of Correlation

\begin{tabular}{cc}
\hline Extent & Range \\
\hline Very Strong & 0.91 to $1.00 /-0.91$ to -1.00 \\
Strong & 0.71 to $0.90 /-0.71$ to -0.90 \\
Moderate & 0.51 to $0.70 /-0.51$ to -0.70 \\
Weak & 0.31 to $0.50 /-0.31$ to -0.50 \\
Very Weak & 0.01 to $0.30 /-0.01$ to -0.30 \\
No Relationship & 0.00 \\
\hline (Source: Bryman \& Cramer, 2005) &
\end{tabular}

\subsubsection{Correlation between Compensation and Benefits with Employee Performance}

Table 8. Correlation between Compensation and Benefits with Employee Performance

\begin{tabular}{lcc}
\hline \multicolumn{1}{c}{ Independent Variables } & Pearson Correlation & $\begin{array}{c}\text { Significant } \\
\text { Value }\end{array}$ \\
\hline Compensation and benefits & 0.317 & 0.003 \\
Remuneration & 0.301 & 0.005 \\
Allowance & 0.243 & 0.024 \\
Promotion & 0.275 & 0.010 \\
Incentives & 0.249 & 0.021 \\
\hline
\end{tabular}

Based on the result obtained from Table 4.6, it shows that compensation and benefits have a positive relationship with employee performance with a correlation value of 0.317 . Further, the strength of the relationship is low. Additionally, the significant value is 0.003 which is less than 0.05 . This shows that these two variables are related. 
Meanwhile, the remuneration also have a positive correlation with employee performance with correlation value of 0.301 that show a low strength. The two variables also related with significant value of 0.005 .

Next, Table 4.6 shows that there is a positive relationship between allowance and employee performance with a correlation value of 0.243 . The strength of the relationship of the two variable is weak. In addition, the significant value is 0.024 which is less than 0.05 . This shows that these two variables are related. Moreover, there is a positive relationship between promotion and employee performance with a correlation value of 0.275 . The strength of the relationship of the two variable is weak. In addition, the significant value is 0.010 which is less than 0.05. This shows that these two variables are related. Lastly, incentive shows the positive relationship employee performance with a correlation value of 0.249 . The strength of the relationship of the two variable is weak. In addition, the significant value is 0.021 which is less than 0.05 . This shows that these two variables are related.

\subsection{Regression Analysis}

\subsubsection{Simple Linear Regression Analysis}

Table 9. Simple Linear Regression between Independent and Dependent Variable

\begin{tabular}{lcccc}
\hline & $\begin{array}{c}\text { Standardized } \\
\text { Coefficients }\end{array}$ & & \\
\cline { 2 - 3 } Variable & Beta & & S \\
\hline (Constant) & & & \\
Compensation and benefits & 0.317 & 3.058 & 0.003 \\
\hline
\end{tabular}

The table 4.7 shows the simple linear regression between independent and dependent variable in which the independent variable are compensation and benefits; dependent variable is overall employee performance. It is found that the independent variable: compensation and benefits $(\beta=0.317, \mathrm{p}=0.003)$ have a significant positive effect on employee performance.

\subsubsection{Multiple Regression Analysis}

Table 10. Multiple Regression of Independent Variable on Dependent Variable

\begin{tabular}{cccccc}
\hline $\mathrm{R}$ & $\mathrm{R}$ Square & $\begin{array}{c}\text { Adjusted R } \\
\text { Square }\end{array}$ & $\begin{array}{c}\text { Std. Error of the } \\
\text { Estimate }\end{array}$ & $\mathrm{F}$ & Sig F \\
\hline .317 & .100 & .089 & 0.46848 & 9.354 & 0.003 \\
\hline
\end{tabular}

Table 4.8 shows F statistic for the final model is 9.354 with $\mathrm{P}$-values of 0.003 , which indicating a significant model. The significant model indicates that there are effect between independent variable with $\mathrm{R}=0.317$. The variance in overall employee performance $\left(\mathrm{R}^{2}=\right.$ 0.100 ) and $8.9 \%$ of in real population (Adjusted $R^{2}=0.089$ ).

Based on the table, the most important piece of information is the $\mathrm{R}$ square. $\mathrm{R}$ square represents the total percentage of variance explained by compensation and benefits. It was shown that the value of $\mathrm{R}$ square was only $10 \%$ thus, exhibiting the variables which are compensation and benefits are very low in effect the employee performance. 


\section{Discussions of Finding}

Table 11. Summary on the Level of Employee Performance

\begin{tabular}{cccc}
\hline Employee performance & Level & Frequency & Percentage \\
\hline 3.00 & Average & 40 & 46.5 \\
4.00 & High & 53.5 & 53.5 \\
\hline
\end{tabular}

The first objective of the research is to measure the level of employee performance among lecturer in XYZ College. Based on table 5.1 in general, majority the level of employee performance is high which is $53.5 \%$ while there are $46 \%$ employee have a high level of performance. However, there are no low and very high level of employee performance. Previous studies also mention that compensation is useful instrument for the management to contribute to organizational and can impact positively on the behaviour and productivity [5].

Table 12. Summary Results of the Hypotheses on Compensation and Benefits with Employee Performance.

\begin{tabular}{cccc}
\hline Hypotheses & Correlation & $\begin{array}{c}\text { Significant } \\
\text { Value }\end{array}$ & Hypotheses \\
\hline H1 & 0.317 & 0.003 & Accepted \\
H2 & 0.301 & 0.005 & Accepted \\
H3 & 0.243 & 0.024 & Accepted \\
H4 & 0.275 & 0.010 & Accepted \\
H5 & 0.249 & 0.021 & Accepted \\
\hline
\end{tabular}

The second objective of this research is to identify the relationship of compensation and benefits with employee performance. Based on Table 5.2, the result shows the compensation and benefits with employee performance significantly related since the significant value is 0.003 which is less than 0.050 . Therefore this concludes that provided the compensation and benefits towards employee such as remuneration, allowance, promotion and incentive can lead to high level of performance. This is supported by Ju, Kong, Hussin, and Jusoff [47], where their finding suggested that both mandatory and positive relationship with organizational commitment and fringe benefits were having a higher relationship as compare to mandatory benefits [47]. The hypothesis for allowance is accepted with significant value of 0.005 . based on Monica Indrayanti and Willen J.F. Alfa [48] finding, they indicates that there are significant effect between compensation and benefits with employee performance [48]. The result also shows that there is relationship between promotions with employee performance with the significant value of 0.010. Ghaffari, Shah, Burgoyne, Nazri, and Salleh [49] state the promotion is an enhancement of the employee's current position [49]. This is because, recognition is required in a social and organizational environment as a motivational tool to produce good results based on their research, they find that promotion is likely important in increasing employee performance because the upwards movement of employee rank in the organization will increase the motivation of employee and their sense of responsibility. The fifth hypothesis also shows the relationship with the employee performance with the significant value of 0.021 . According to Oun [34], the positive effect of incentives are used as a lead to show employees what organization want to accomplish and what they assessment and prioritize as significant to their work and it is used as an effective tool to attract employee who are desirable, authoritative into the organization, because employee who appreciate this 
form of magnetism will be interesting to work there rather than employee that only looking for steady benefits [34]. Besides, incentives known as a performance-based compensation system that links employee compensation to the achievement of workers who works directly in the workplace [32].

The third objective is regression which shows that there are exist significant value and it is found that the independent variable: compensation and have a significant positive effect on employee performance. The performance of the employee can only increase if there is compensation and benefits that act as motivator. In order to boost the level of performance the organizational must plan the effective strategies for employee. The compensation and benefits can help to increase the level of performance but there are other factors that contribute more in increase the level of performance. There are low correlation and regression which means that the relationship between compensation and benefits and employee performance is very weak. This also means that compensation and benefits not only factor that influence performance. There are other main factor that more important. Organizational should focus on other factor besides of rewards such as supportive and caring environment and good working condition that allow employee to balance the personal and professional spheres [50].

\section{Recommendation}

The organization need to develop and implemented strategies of provide the effective compensation and benefits to increase the level of employee performance. For example, adjust a real wage system in accordance with the established wage structure by process and evaluate the information from labour market and internal policies of the organization [51].

In addition, future studies should try to cover a larger geographical area and to compare the result received from different country and educational organization of different size. This will ensure a broad spectrum of respondent and show how the geographical location and size of an organization has an influence on employee level performance such as private sector of educational institution.

\section{Conclusion}

Employee performance is very important in contribute to the organizational success. In order to boost the level of performance the organizational must plan the effective strategies for employee. The compensation and benefits can help to increase the level of performance but there are other factor that contribute more in increase the level of performance. Organizational should focus on other factor besides of rewards such as supportive and caring environment and good working condition that allow employee to balance the personal and professional spheres [50].

\section{References}

[1] Dessler, G. (2015). Human resource management. Boston: Pearson.

[2] Feraro-Banta, L., \& Shaikh, S. Al. (2017). Relation of Compensation and Benefits on Employees' Performance: A Study of Audit Firms in Bahrain. Iarjset, 4(5), 175-183. https://doi.org/10.17148/IARJSET.2017.4533

[3] Samnani, A. K., \& Singh, P. (2014). Performance-enhancing compensation practices 
and employee productivity: The role of workplace bullying. Human Resource Management Review, 24(1), 5-16. https://doi.org/10.1016/j.hrmr.2013.08.013

[4] Woodruffe, C. (2006). The crucial importance of employee engagement. Human Resource Management International Digest, 14(1), 3-5

[5] Mabaso, C. M., \& Dlamini, B. I. (2017). Impact of Compensation and Benefits on Job Satisfaction. Research Journal of Business Management, 11(2), 80-90. https://doi.org/10.3923/rjbm.2017.80.90

[6] Kar, B., Panda, Madhu, C., Pathak, Mallika, D. (2019). Women's Work Life Balance: Compensation is the Key. Journal of Management Research (09725814) . Jan-Mar2019, Vol. 19 Issue 1, p29-40. 12p.

[7] Larbi, T.-A. (2014). Effect of Compensation Management on Employee Performance At the St . Michael' S Catholic Hospital, Pramso. Human Resource and Organizational Development, (July), 1-80.

[8] Yeung, R., Gigliotti, P. \& Nguyen-Hoang, P. Res High Educ (2019) 60: 1. ttps://doi.org/10.1007/s11162-018-9501-7

[9] Adeoye, A. O. (2014). An Assessment of Compensation Management and Motivation on. Management, Information Technology and Governance.

[10] Anto, M. L. (2018). Talent Management of Multinational Companies in the Kingdom of Bahrain. Bussiness and Management, 10(5), 5-8.

[11] Salisu, J. B., Chinyio, E., \& Suresh, S. (2015). The impact of compensation on the job satisfaction of public sector construction workers of jigawa state of Nigeria. The Business and Management Review, 6(4), 10-11.

[12] Berber, N., Morley, M. J., Slavić, A., \& Poór, J. (2017). Management compensation systems in Central and Eastern Europe: a comparative analysis. The InTernaTIonal Journal of human resource managemenT, 28(12), 1661-1689.

[13] Soon, C. S., Brass, M., Heinze, H. J., \& Haynes, J. D. (2008). Unconscious determinants of free decisions in the human brain. Nature neuroscience, 11(5), 543.

[14] Nyangi, P. A. (2011). Perceived effects of employee benefits on employee retention at Kenya Forest Service (Doctoral dissertation).

[15] Hina, Q., Zamir, S., \& Nudrat, S. (2014). Impact of employee benefits on job satisfaction of teachers at higher level. Journal of Education and Practices, 5(7), 122 $129 . \quad$ Retrieved from http://citeseerx.ist.psu.edu/viewdoc/download?doi=10.1.1.976.8782\&rep=rep1\&type=p df

[16] Dar, L., Akmal, A., Naseem, M. A., \& din Khan, K. U. (2011). Impact of stress on employees job performance in business sector of Pakistan. Global journal of management and business research, 11(6).

[17] Siramiati, N. W., Surachman, Hadiwidjojo, D., \& Rohman, F. (2016). PerformanceBased Compensation Effect On Employee Motivation, Satisfaction Of Employees, And Performance Of Employees (Study On Private Universities In The Province Of Bali): Conceptual Frameworks. International Journal of Business, Economics and Law, ISSN: 2289-1552, 11(2), 62-70. Retrieved from http://ijbel.com/wpcontent/uploads/2017/02/BUS-215.pdf

[18] Odunlami, I. B., \& Matthew, A. O. (2014). Compensation Management and Employees Performance in the Manufacturing Sector, A Case Study of a Reputable Organization in the Food and Beverage Industry. International Journal of Managerial Studies and Research, 2(9), 108-117.

[19] Purnama, M. S. (2017). the Effect of Direct and Indirect Compensation To Employee'S 
Loyalty: Case Study At Directorate of Human Resources in Pt Pos Indonesia. Journal of Indonesian Applied Economics, $\quad 7(1), \quad$ 84-102. https://doi.org/10.21776/ub.jiae.2017.007.01.6

[20] Bender, K. A., \& Heywood, J. S. (2010). Out of balance?: Comparing public and private sector compensation over 20 years.

[21] Maicibi, N. A. (2005) Pertinent Issues in Management: Human Resource and Educational Management. Net Media Publishers, Kampala First ed.

[22] Boselie P, Dietz G, Boon C (2005) Commonalities and contradictions in HRM and performance research. Hum Resour Manage J 15(3):67-94

[23] Zamer, H., Alireza, S., Nisar, W., \& Amir, M. (2014). The Impact of the Motivation on the Employeeâ\&\#128;\&\#153;s Performance in Beverage Industry of Pakistan. International Journal of Academic Research in Accounting, Finance and Management Sciences, 4(1), 293-298. https://doi.org/10.6007/IJARAFMS/v4-i1/630

[24] Agwu, M. O. (2013). Impact of Fair Reward System on Employees Job Performance in Nigerian Agip Oil Company Limited Port-Harcourt. British Journal of Education, Society \& Behavioural Science, 3(1), 47-64. https://doi.org/10.9734/BJESBS/2013/2529

[25] Prasad, C. V. 2015. Emerging trends in HRM. International Journal of Economic Research, 12(2): pp. $511-517$.

[26] Armstrong, M. (2006). Performance management: Key strategies and practical guidelines.

[27] Muguongo, M.M., Muguna, A.T., dan Muriithi, D.K. 2015. Effects of Compensation on Job Satisfaction Among Secondary School Teachers in 13 Maara Sub - County of Tharaka Nithi County, Kenya., Vol. 3, No. 6, pp. 47-59.

[28] W.D. McCausland, K. Pouliakas, I. Theodossiou, (2005) "Some are punished and some are rewarded: A study of the impact of performance pay on job satisfaction", International Journal of Manpower, Vol. 26 Issue: 7/8, pp.636659, https://doi.org/10.1108/01437720510628112

[29] Gathungu, E. W. M., Iravo, M. A., \& Namusonge, G. S. (2015). Effect of Promotion Strategies on the Organizational Commitment of Banking Sector Employees in Kenya. IOSR Journal Of Humanities And Social Science Ver. I, 20(10), 36-45. https://doi.org/10.9790/0837-201013645

[30] Brenya, R., Weijun, C., \& Kipkemboi, R. B. (2018). Factors Affecting Academic Staff And Their Impact On The University : A Case Study Of Nuist, 7(February), 71-82.

[31] Osibanjo, O. A., Adeniji, A. A., \& Olubusayo, H. (2014). Compensation packages : a strategic tool for employees ' performance and retention. Journal of Sciences, (25), 6584.

[32] Mathis, R. L., \& Jackson, J. H. (2011). Human resource management: Essential perspectives. Cengage Learning.

[33] Lai, C. (2009). Motivating employees through incentive programs.Hazzi, O., \& Maldaon, I. (2015). A Pilot Study: Vital Methodological Issues. Verslas: Teorija Ir Praktika, 16(1), 53-62. https://doi.org/10.3846/btp.2015.437

[34] Oun, T. (2015). A Thesis submitted to Victoria University of Wellington in partial fulfillment of the requirement for the degree of Master of Ma.

[35] Dewhurst, M., Guthridge, M. \& Mohr, E. (2010). Motivating people: getting beyond money. McK- insey Quarterly, (1), 12-15

[36] Sultana, Afshan \& Irum, Sobia \& Ahmed, Kamran \& Mehmood, Nasir. (2012). Impact of training on employee performance: A study of telecommunication sector in Pakistan. INTERDISCIPLINARY JOURNAL OF CONTEMPORARY RESEARCH IN 
BUSINESS. 4. 646-661.

[37] Pradhan, R. K., \& Jena, L. K. (2017). Employee Performance at Workplace: Conceptual Model and Empirical Validation. Business Perspectives and Research, 5(1), 69-85. https://doi.org/10.1177/2278533716671630

[38] Charbonnier-Voirin, A., \& Roussel, P. (2012). Adaptive performance: A new scale to measure individual performance in organizations. Canadian Journal of Administrative Sciences, 29(3), 280-293. https://doi.org/10.1002/CJAS.232

[39] Maynard, M. T., Kennedy, D. M., \& Sommer, S. A. (2015). Team adaptation: A fifteenyear synthesis (1998-2013) and framework for how this literature needs to "adapt" going forward. European Journal of Work and Organizational Psychology, 24(5), 652677.

[40] Conway, J. M. (1999). Distinguishing contextual performance from task performance for managerial jobs. Journal of applied Psychology, 84(1), 3.

[41] Reilly, R. R., \& Aronson, Z. H. (2017). Managing contextual performance. Performance Management: Putting Research into Action., (December 2012), 297-328. Retrieved from

http://ovidsp.ovid.com/ovidweb.cgi?T=JS\&PAGE=reference $\& D=p s y c 6 \& N E W S=N \& A$ $\mathrm{N}=2009-17503-009$

[42] Podsakoff, P. M., \& MacKenzie, S. B. (1994). An examination of the psychometric properties and nomological validity of some revised and reduced substitutes for leadership scales. Journal of Applied Psychology, 79(5), 702.

[43] Motowidlo, S. J., \& Van Scotter, J. R. (1994). Evidence that task performance should be distinguished from contextual performance. Journal of Applied psychology, 79(4), 475.

[44] Lind, D. A., Marchal, W. G., \& Mason, R. D. (2002). Statistical techniques in business \& economics (Vol. 1). Irwin Professional Publishing.

[45] Hazzi, O., \& Maldaon, I. (2015). A pilot study: Vital methodological issues. Business: Theory and Practice, 16, 53.

[46] Mallery, P., \& George, D. (2003). SPSS for Windows step by step: a simple guide and reference. Allyn, Bacon, Boston, .

[47] Ju, S., Kong, L., Hussin, Z. H., \& Jusoff, K. (2009). The Influence of Employee Benefits Towards Organizational Commitment. Asian Social Science, 4(8), 147-150. https://doi.org/10.5539/ass.v4n8p147

[48] Monica Indrayanti, S., \& Willen J.F. Alfa, T. (2016). The Influence of Performance Allowance and Employee Development To Employee Performance in State Assets and Service Office Manado. The Influence Of ..., 4(1), 1156-1165.

[49] Ghaffari, S., Shah, I., Burgoyne, J., Mohd Nor, M., \& Salleh, J. (2017). The influence of motivation on job performance: A case study at Universiti Teknoligi Malaysia.

[50] Peluso, A. M., Innocenti, L., \& Pilati, M. (2017). Pay is not everything. Evidence-Based HRM: A Global Forum for Empirical Scholarship, 5(3), 311-327. https://doi.org/10.1108/EBHRM-07-2015-0031

[51] Urbancová, H., \& Šnýdrová, M. (2017). Remuneration and employee benefits in organizations in the Czech Republic. Acta Universitatis Agriculturae et Silviculturae Mendelianae Brunensis, 65(1), 357-368. 